\title{
The Allelopathic Effect of Dill Plant (Anethum graveolens L.) Residues on the Growth and Chemical Content of Two Types of Barley (Hordeum vulgare L.) Cultivars
}

\author{
Pakhshan M. Maulood \\ Shireen A. Amin \\ Department of Biology \\ College of Science \\ University of Salahaddin \\ Erbil, Iraq
}

(Received 3/10/2011;Accepted 14/2/2012)

\begin{abstract}
A pot experiment was conducted at the greenhouse of Science College- Salahaddin University-Erbil, Iraq, during November 2009 to April 2010 to study the effect of different concentration of dill plant residue (added to soil at ratio $0,2,4$, and $6 \% \mathrm{~W}$ : $\mathrm{W}$ mixed and incubated for four weeks) on some vegetative growth characters and chemical composition of leaves and grains of two barley cultivars $\left(\mathrm{C}_{1}=\right.$ Tedmor, $\mathrm{C}_{2}=$ Barbara $)$. The results indicated that the different concentration of dill plant residue were affected significantly $(\mathrm{P} \leq$ 0.05) on most growth characters except number of tiller/plant. The highest values for all studied growth characters were recorded at $2 \%$ of dill plant residue for both cultivars. On the other hand, statistical analysis showed significant $(\mathrm{P} \leq 0.05)$ differences between two cultivars on nutrient content of leaves and seeds. In general, increasing level of dill plant residue led to significant increase of nitrogen, protein percent, proline, phosphorus, $\mathrm{Fe}, \mathrm{K}^{+}$, and $\mathrm{Na}^{+}$content of the leaves in both cultivars.
\end{abstract}

Keywords: Allelopathy, Dill plant residues, Barley.

\section{التأثير لاليلوساثي لبقليا نبلت الثبت (Anethum graveolens L.)في النمو والمحتوى الكيمياوي لصفينمن الثعير ي (Hordeum vulgare L.)}

\section{الملغص}

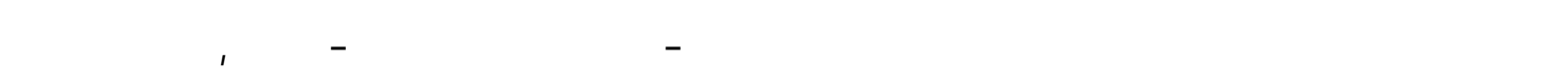

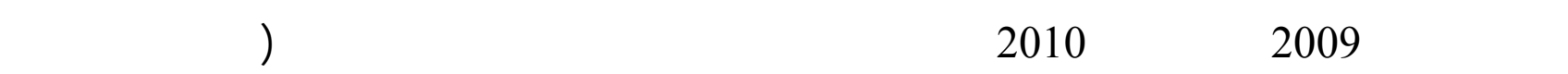

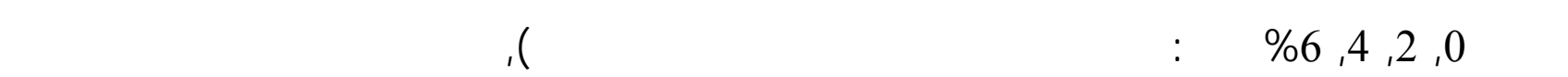

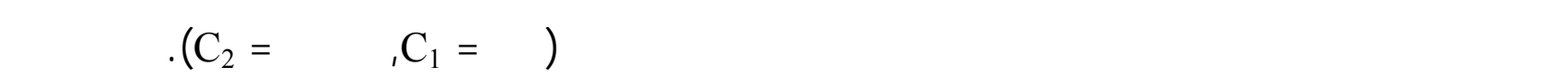

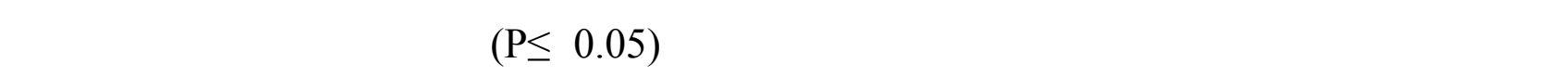


الأفرع/ نبلت. أعلى القيم للك الصفات المدروسةسجلت في تركيز 2\% من بقايا نبلت للثبت لكلا الصفين.

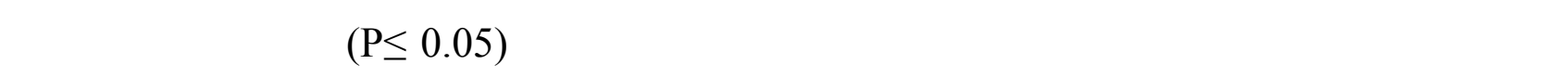

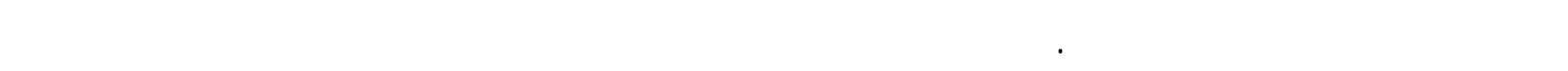

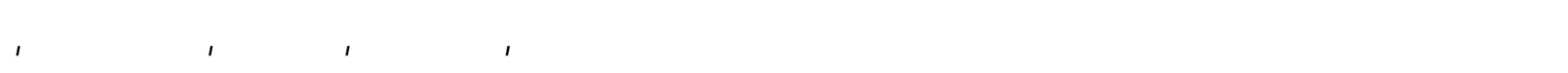
ومحتوى الصوديوم في أوراق كلا الصفين.

\section{INTRODUCTION}

Allelopathy is defined as the direct or indirect harmful or beneficial effects of one plant on another through the production of chemical compounds that escape into the environment (Kremer and Ben- Hammouda, 2009). Most plants exhibit allelopathic effects on seed germination, growth and development of other plants by releasing allelochemicals into the soil, either as exudates from living organs or by decomposition of plants residues (Mutlu and Atiei, 2009).

The release of active substances can be as the result of at least four different processes: volatilization, decomposition, leaching of plant residues in the soil, and root exudation ( ElRokiek et al., 2010). The release metabolites can inhibit or delay germination and also inhibit or stimulate the growth of roots and shoot of neighboring plants (Ninkovic, 2003).

Weeds can also affect a crops growth by releasing allelochemicals into the growing environment. All plant parts of the weed including leaf, stem, root, and fruit have allelopathic potential. However, various parts of weeds show different behavior in exerting their allelopathic effects on crops. Weeds also exert allelopathic effects on crop seed germination and growth by releasing water- soluble compounds into the soil (kivi and Tobeh, 2010 ; Zuo et al., 2008).

Barley (Hordeum valgare L.), a plant widely cultivated around the world, has had widespread use as a health food. It has abundant protein, minerals, enzymes, and antioxidants, as well as, anti- inflammatory and antiviral properties by various biologically active materials (Edrisi and Farahbakhsh, 2011; choe et al., 2010; Ahmed et al., 2007). In Iraq barley is an important cereal crop. It is grown for grain and pasture for livestock, frequently for both purposes during the same growing season. Farmers typically produce continuous barley crops under rain- fed conditions (Amin, 2010).

Barley is well known for its allelopathic compounds. Several phenols and terpens have been reported in various cultivars of barley ( Ashrafi et al., 2009), also it found to be phytotoxic to durum wheat (Triticum durum Desf.) and bread wheat (Triticum aestivum L.) (Ashrafi et al., 2008). On the other hand, release of volatile compounds from other plants such as Artemisia tridentates Nutt. and Sasa cernua Makino inhibited the growth of barley seedling and decreased the respiration rate of germination seeds (Ninkovic, 2003).

Dill (Anethum graveolens L.) is a short- lived perennial herb plant belonging to family Umbelliferae (Apiaceae) (Radulescu et al., 2010). Wild and weedy types of dill are widespread in the Mediterranean basin and in West Asia (Callan et al., 2007). Dill is one of the first known multipurpose aromatic plants which have been used as a spice and medicine (Hellal et al., 2011). Dhima et al., (2009) found that the green manure of aromatic plants, such as dill plant, significantly suppressed the emergence and growth of barnyard grass 
(Echinochola crus- galli L.). While, essential oil extracted from dill plant caused reduction in germination, root length and total fresh weight of barnyard grass (Dhima et al., 2010). Xing (2009) noticed that the significant effect of dill plant extracted oil on tuber sprout number and weight of potatoes. Therefore, the objective of the present work was to investigate the allelopathic effect of dill plant residues (Anethum graveolens L.) on some vegetative growth and chemical components of two barley cultivars.

\section{MATERIALS AND METHODS}

The dill plant was collected in the farm by cutting the upper growing parts (shoot) at the soil level and immediately brought to the laboratory. The collected plant cut in $2-3 \mathrm{~cm}$ pieces and oven dried at $40^{\circ} \mathrm{C}$ for $48 \mathrm{hrs}$. The dried plant was ground to fine powder (passed through a $1.5 \mathrm{~mm}$ mesh). The prepared powder was kept in dark plastic jar and stored at $20{ }^{\circ} \mathrm{C}$ until used.

The investigation was carried out in the greenhouse of Biology department, College of Science, Salahaddin University- Erbil, Iraq, from November 2009 to April 2010. Ground dried dill plant were mixed thoroughly with soil at the ratio $0,2,4,6 \% \mathrm{~W}: \mathrm{W}$, the mixture placed in nylon bags and moisture with tap water then incubated for 4 weeks to allow natural decay of the dill plant residues. Then, the pots were sown with barley seeds ( 3 seeds/pot), (two barley varieties were used, $\mathrm{C}_{1}=$ Temdor and $\mathrm{C}_{2}=$ Barbara).

The soil used in the experiment brought from quarries of Aski-kalak. The soil was dried and passed through $2 \mathrm{~mm}$ sieve; and some physico- chemical analysis were measured according to procedure described by (Ryan et al., 2001) and results is summarized in table (1).

Samples of barley cultivars were taken after physiological maturity. Some vegetative growth characteristics were measured for each treatments includes: the plant height, number of leaves, tillers, spike/plant, number of kernel/ spike, flag leaf area, weight of 100 kernel and weight of dry matter of plant. The plant harvested, separated into different plant parts (straw, seeds), oven dried at $75^{\circ} \mathrm{C}$ for $24 \mathrm{hrs}$. Chemical analysis for leaves and grains were determined after acid digestion for samples $\left(0.5 \mathrm{gm}\right.$ dried plant with $\left.\mathrm{H}_{2} \mathrm{SO}_{4}+\mathrm{H}_{2} \mathrm{O}_{2}\right)$. Total nitrogen and protein content were determined using modified Kjeldhal method, where, $\mathrm{Na}^{+}$ and $\mathrm{K}^{+}$determined by flame photometer (Jenway, PFP7). Phosphorus by spectrophotometric method (JENWAY model 6300) according to (Schuffelen et al., 1960), also Fe by spectrophotometric method at 480nm as recommended by (Vogel, 1961). Total chlorophyll content in leaves was extracted and determined at $(665,649 \mathrm{~nm})$ according to (Knudsen et al., 1997), Proline according to (Bates et al., 1973).

The experiments were designed as Factorial experiment in Completely Randomized Design (Factorial C.R.D), with four replications. The data were subjected to standard analysis of variance and means were compared at significant 5\% level by Duncan test.

\section{RESULTS AND DISCUSSION}

Table (2) indicated that the barley cultivars were not affected significantly $(\mathrm{P} \leq 0.05)$ on dry weight, number of spike; tiller per plant and length of plant. While the cultivars affected significantly on weight of 100seed; number of leaf per plant; number of seed per spike and leaf area. The highest values $3.31 \mathrm{gm} ; 26.31 ; 33.4$ and $13.17 \mathrm{~cm}^{2}$ respectively was recorded for cultivars Barbara $\left(\mathrm{C}_{2}\right)$. These results are in accordance with other studies which reported 
the differences and similarities between the barley cultivars (Edrisi and Farahbakhsh, 2011; choe et al., 2010; Oueslati et al., 2005; Ninkovic, 2003).

It is obvious from table (2) that the application of different concentration of dill plant residues effected significantly $(\mathrm{P} \leq 0.05)$ on all studied growth characters except number of tiller per plant. The dry weight and the weight of 100kernel increased significantly with increasing levels of dill plant residues and the highest values $(4.76,3.33 \mathrm{gm})$ were recorded at $6 \%$ dill plant residue $\left(\mathrm{A}_{4}\right.$ treatment). These results are disagreement with previous studies they commented that increase concentration of plant residue caused decrease of growth characters such as dry weight, length of plant, weight of 100kernel ( El- Rokiek et al., 2010; Kivi et al., 2010; Ashrafi et al., 2008). Also the significant differences were recorded among all treatments except $\mathrm{A}_{3}$ and $\mathrm{A}_{4}$ for dry weight and weight of $100 \mathrm{kernel}$. Growth of barley, as indicated by number of leaf and leaf area significantly $(\mathrm{P} \leq 0.05)$ reduced by increasing rates of dill plant residue (Fig. 1 and 2). The highest value 28 leaf /plant and 15.4 $\mathrm{cm}^{2}$ were obtained at $2 \%$ dill plant residue. The results of the present study and previous work (El- Rokiek et al., 2010; Kivi et al., 2010; Ashrafi et al., 2009; Ashrafi et al., 2008; Dhima et al., 2009) show that increase of concentration caused to decrease of growth character. This may be attributed to short- term allelopathic and autotoxic effects (Ashrafi et al., 2009). Meanwhile the longest plant length $55.13 \mathrm{~cm}$ was recorded at $4 \%$ dill plant residue (Figure 3).

Table (2) illustrated the combined effect of different concentration of dill plant residues and cultivars affected significantly $(\mathrm{P} \leq 0.05)$ on all studied growth characters except number of tillers per plant. Under different concentration of dill plant residue, Tadmor cultivars $\mathrm{C}_{1}$ recorded the highest value 5.30 and $3.09 \mathrm{gm}$ of dry weight and weight of 100 seed were recorded at $6 \%\left(\mathrm{~A}_{4}\right)$ respectively of dill plant residues. While in Barbara cultivars $\mathrm{C}_{2}$ the highest value $5.79 \mathrm{gm}$ of dry weight was recorded at $4 \%$ of dill plant residue. On the other hand, the highest values were obtained at $2 \%$ of dill plant residues for most studied growth characters in both cultivars. Similar results were obtained by (Dhima et al., 2009; Mutlu and Atiei, 2009; Ashrafi et al., 2008 ; Oueslati et al., 2005; Ninkovic, 2003) that the increase of concentration led to decrease growth character among different plant species and cultivars.

There was a significant differences between the two cultivars on the proline, nitrogen, protein percent, $\mathrm{K}^{+}$and $\mathrm{Na}^{+}$content of the leaves, table(3). The highest value of these nutrients was recorded for cultivars $\left(\mathrm{C}_{1}\right)$. Although, there were no significant differences $(\mathrm{P} \leq 0.05)$ between two cultivars on the total chlorophyll, $\mathrm{P}$ and Fe content of the leaves. These results are in accordance with other studies which reported that there is differences and similarities between different barley cultivars on chemical components of plant (Choe et al., 2010; Amin, 2010; Dhima et al., 2010; Kremer and Ben- Hammouda, 2009; Dhima et al., 2009).

It is obvious from table (3) that the application of different level of dill plant residue were affected significantly $(\mathrm{P} \leq 0.05)$ on most of the studied nutrient content of the barley leaves except total chlorophyll content. The highest value $89.6 \mathrm{ppm}, 7.64,19.84 \%$ and $9.87 \mathrm{ppm}$ were obtained at $2 \%$ of dill plant residue $\left(\mathrm{A}_{2}\right.$ treatment) for proline, total nitrogen, protein percent and Fe respectively of barley leaf content. Fig. (4) showed total phosphorus content of the leaves that increased significantly with increasing concentration of the dill plant residue. The highest value $70.13 \mathrm{mg} \cdot \mathrm{g}^{-1}$ was obtained at $6 \%$ dill plant residue. On the other hands the highest value $1.1 \mathrm{mg} \cdot \mathrm{g}^{-1}$ of $\mathrm{Na}^{+}$content was recorded at control treatment 
(Fig. 5). Overall significant differences were recorded among all treatment. These results are agreement with (El- Rokiek et al., 2010), this may be due to that the dill plant contain many chemical component such as phenol compound, flavoid, volatile oil, organic acid (Badar et al., 2008), there the morphological and physiological effects of phenolic acids on susceptible plants are reduced leaf expansion, leaf production, net carbon assimilation rate and stomatal conductance, then decreases leaf water potential due to reduced osmotic potential and turgor pressure and lower nutrient content in roots and shoots (Kremer and Ben- Hammouda, 2009).

Table (3) indicates significant effect of combination between different rates of dill plant residue and barley cultivars are affected significantly $(\mathrm{P} \leq 0.05)$ on chemical composition of leaf. In general increasing level of application of dill plant residue caused significant increasing level in $\mathrm{N}$, protein, $\mathrm{P}, \mathrm{Fe}, \mathrm{K}^{+}$and $\mathrm{Na}^{+}$content of the leaf in Tedmor cultivars $\left(\mathrm{C}_{1}\right)$, meanwhile the highest value of these nutrients was recorded in Barbara cultivar $\left(\mathrm{C}_{2}\right)$ was recorded at $2 \%$ of dill plant residue $\left(\mathrm{A}_{2}\right)$ treatment. However, total chlorophyll, proline, $\mathrm{N}$, protein percent, $\mathrm{P}, \mathrm{K}^{+}$and $\mathrm{Na}^{+}$content were comparatively more in $\mathrm{C}_{2}$ than $\mathrm{C}_{1}$. Overall there were significant differences between two cultivars under different rates of dill plant residue. These results come accordance with other studies which reported that allelopathicity may vary among different plant cultivars under different concentration of plant extract (Kivi et al., 2010; Oueslati et al., 2005; Chon and Kim, 2002; Economou et al., 2002).

It is illustrated from table (4) that the cultivars effected significantly $(\mathrm{P} \leq 0.05)$ on each total nitrogen, protein percent, $\mathrm{P}$ and $\mathrm{K}^{+}$content of barley grain. The highest value 7.16, $18.18 \%$ and $43.46 \mathrm{mg} / \mathrm{gm}$ except $\mathrm{K}^{+}$content was recorded for cultivars Barbara $\left(\mathrm{C}_{2}\right)$ for nitrogen, protein percent and phosphorus content respectively. On the other hand, there were no significant differences between the cultivars on the $\mathrm{Fe}$ and $\mathrm{Na}$ content of the seeds. This result is agreement with those obtained by (Amin, 2010).

It is clarifies from table (4) that the application of different concentration of the dill plant residue were affected significantly $(\mathrm{P} \leq 0.05)$ on the chemical content of the barley seeds. Generally, increasing rates of dill plant residue caused significant increasing in nitrogen, protein percent, $\mathrm{K}^{+}, \mathrm{Na}^{+}$and $\mathrm{P}$ content of the barley grain. The highest value 7.43, $19.13 \%, 31.87$ and $1.39 \mathrm{mg} / \mathrm{gm}$ were recorded respectively for previous contents except for Phosphorus low content recorded at $6 \%$ dill plant residue $\left(\mathrm{A}_{4}\right.$ treatment). On the other hand, the highest value $3.66 \mathrm{ppm}$ of the Fe content was obtained at control treatment.

Both cultivars and different rates of dill plant residue showed significant $(\mathrm{P} \leq 0.05)$ effect on the chemical composition of the barley seed (Table 4). Overall increasing rates of the dill plant residue led to significant increasing in nitrogen, protein percent, $\mathrm{K}^{+}, \mathrm{Na}^{+}$and $\mathrm{P}$ content of the seed in Barbara cultivars $\left(C_{2}\right)$. The highest value $8.42,21.24 \%, 34.83$, $1.73 \mathrm{mg} / \mathrm{gm}$ were recorded in $\mathrm{C}_{2}$ for nitrogen, protein percent, $\mathrm{K}^{+}$and $\mathrm{Na}^{+}$content respectively at $6 \%$ dill plant residue. Meanwhile, the highest value $7.06,18.03 \%, 3.28 \mathrm{ppm}$, $29.58 \mathrm{mg} / \mathrm{gm}$ were recorded for nitrogen, protein percent, Fe and $\mathrm{K}^{+}$content respectively at $2 \%$ of the dill plant residue for Tedmor $\left(\mathrm{C}_{1}\right)$. On the other hand, increasing level of the dill plant residue caused to significant decrease in total phosphorus content of the seed in $\mathrm{C}_{1}$, the highest value $15.89 \mathrm{mg} / \mathrm{gm}$ was recorded at control treatment. 
Table 1: Some chemical and physical properties of the soil used in the experiment.

\begin{tabular}{|c|c|}
\hline Parameters & Value \\
\hline PSD g. $\mathrm{Kg}^{-1} \quad$ Clay & 52.0 \\
\hline Silt & 251 \\
\hline Sand & 697 \\
\hline \multicolumn{2}{|c|}{ Sandy loam } \\
\hline Organic matter $\%$ & 6.00 \\
\hline Total nitrogen $\%$ & 0.08 \\
\hline $\mathrm{pH}$ & 7.80 \\
\hline EC dS.m ${ }^{-1}$ & 0.608 \\
\hline Soluble ions mmole. $\mathrm{l}^{-1}$ & ---- \\
\hline $\mathrm{HCO}^{-3}$ mmole. $\mathrm{l}^{-1}$ & 3.75 \\
\hline $\mathrm{SO}_{4}{ }^{=} \quad$ mmole. $^{-1}$ & 1.19 \\
\hline $\mathrm{Ca}^{++} \quad$ mmole. $\mathrm{l}^{-1}$ & 2.30 \\
\hline $\mathrm{Mg}^{++} \quad$ mmole. $^{-1}$ & 0.80 \\
\hline mmole. $^{-1}$ & 0.81 \\
\hline mmole. $1^{-1}$ & 0.72 \\
\hline mmole. $^{-1}$ & 1.60 \\
\hline mmole. $^{-1}$ & 0.03 \\
\hline ppm & 2.10 \\
\hline
\end{tabular}


The Allelopathic Effect of Dill Plant.....

Table 2: Combined effects of different concentration of dill plant residues and cultivars on some vegetative growth, data represented as (mean \pm S.E.).

\begin{tabular}{|c|c|c|c|c|c|c|c|c|c|}
\hline & & $\begin{array}{l}\text { Dry weight } \\
\text { (gm) }\end{array}$ & $\begin{array}{c}\text { Weight of } 100 \\
\text { seed (gm) }\end{array}$ & $\begin{array}{c}\begin{array}{c}\text { No. of spike/ } \\
\text { plant }\end{array} \\
\end{array}$ & $\begin{array}{c}\text { No. of tiller/ } \\
\text { plant }\end{array}$ & $\begin{array}{c}\text { No. of leaf/ } \\
\text { plant }\end{array}$ & $\begin{array}{c}\text { No. of seed/ } \\
\text { spike }\end{array}$ & $\begin{array}{l}\text { Length of } \\
\text { plant (cm) }\end{array}$ & $\begin{array}{c}\text { Leaf area } \\
\left(\mathrm{cm}^{2}\right)\end{array}$ \\
\hline \multirow[t]{2}{*}{ Cultivars } & $\mathrm{C}_{1}$ & $4.071 \pm 0.10^{\mathrm{a}}$ & $2.62 \pm 0.086^{\mathrm{a}}$ & $2.94 \pm 0.159^{\mathrm{a}}$ & $3.37 \pm 0.219^{\mathrm{a}}$ & $16.56 \pm 0.447^{\mathrm{a}}$ & $28.88 \pm 0.89^{\mathrm{a}}$ & $46.31 \pm 0.63^{\mathrm{a}}$ & $6.68 \pm 0.11^{\mathrm{a}}$ \\
\hline & $\mathrm{C}_{2}$ & $4.458 \pm 0.10^{\mathrm{a}}$ & $3.31 \pm 0.086^{\mathrm{b}}$ & $3.12 \pm 0.159^{\mathrm{a}}$ & $3.62 \pm 0.219^{\mathrm{a}}$ & $26.31 \pm 0.447^{b}$ & $33.44 \pm 0.89^{b}$ & $50.44 \pm 0.63^{\mathrm{a}}$ & $\begin{array}{c}13.17 \pm \\
0.11^{\mathrm{b}}\end{array}$ \\
\hline \multirow{4}{*}{ 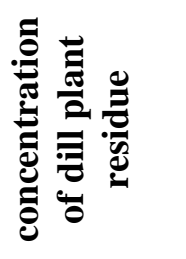 } & $\mathrm{A}_{1}(0 \%)$ & $3.470 \pm 0.14^{\mathrm{a}}$ & $2.335 \pm 0.12^{\mathrm{a}}$ & $2.25 \pm 0.225^{\mathrm{a}}$ & $3.50 \pm 0.31^{\mathrm{a}}$ & $21.5 \pm 0.68^{\mathrm{a}}$ & $28.38 \pm 1.27^{\mathrm{a}}$ & $46.13 \pm 0.89^{\mathrm{a}}$ & $8.84 \pm 0.15^{\mathrm{a}}$ \\
\hline & $\mathrm{A}_{2}(2 \%)$ & $4.129 \pm 0.14^{b}$ & $3.102 \pm 0.12^{\mathrm{b}}$ & $4.13 \pm 0.225^{\mathrm{b}}$ & $3.38 \pm 0.31^{\mathrm{a}}$ & $28.3 \pm 0.68^{b}$ & $37.13 \pm 1.27^{\mathrm{b}}$ & $48.75 \pm 0.89^{\mathrm{b}}$ & $15.4 \pm 0.15^{\mathrm{b}}$ \\
\hline & $\mathrm{A}_{3}(4 \%)$ & $4.696 \pm 0.14^{\mathrm{c}}$ & $3.100 \pm 0.12^{b}$ & $3.63 \pm 0.225^{\mathrm{b}}$ & $3.75 \pm 0.31^{\mathrm{a}}$ & $24.5 \pm 0.68^{c}$ & $32.13 \pm 1.27^{\mathrm{c}}$ & $55.13 \pm 0.89^{\mathrm{c}}$ & $11.1 \pm 0.15^{\mathrm{c}}$ \\
\hline & $\mathrm{A}_{4}(6 \%)$ & $4.764 \pm 0.14^{\mathrm{c}}$ & $3.334 \pm 0.12^{\mathrm{b}}$ & $2.13 \pm 0.225^{\mathrm{a}}$ & $3.38 \pm 0.31^{\mathrm{a}}$ & $11.5 \pm 0.68^{\mathrm{d}}$ & $29.0 \pm 1.27^{\mathrm{ac}}$ & $43.5 \pm 0.89^{d}$ & $4.34 \pm 0.15^{\mathrm{d}}$ \\
\hline \multirow{8}{*}{ 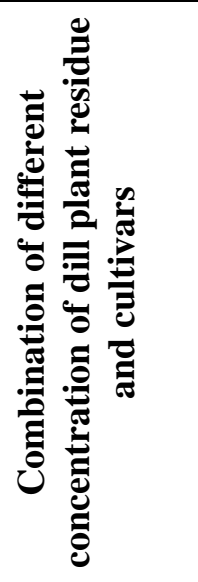 } & $\mathrm{C}_{1} \mathrm{~A}_{1}$ & $3.57 \pm 0.21^{\mathrm{a}}$ & $2.05 \pm 0.22^{\mathrm{a}}$ & $2.25 \pm 0.25^{\mathrm{a}}$ & $4.00 \pm 0.41^{\mathrm{a}}$ & $19.0 \pm 0.92^{\mathrm{a}}$ & $25.0 \pm 1.22^{\mathrm{a}}$ & $43.8 \pm 0.75^{\mathrm{a}}$ & $4.59 \pm 0.37^{\mathrm{a}}$ \\
\hline & $\mathrm{C}_{1} \mathrm{~A}_{2}$ & $3.82 \pm 0.26^{\mathrm{ab}}$ & $2.53 \pm 0.10^{\mathrm{ab}}$ & $3.75 \pm 0.48^{b}$ & $3.00 \pm 0.58^{\mathrm{a}}$ & $20.3 \pm 0.85^{\mathrm{a}}$ & $37.0 \pm 1.47^{\mathrm{c}}$ & $49.0 \pm 0.41^{\mathrm{b}}$ & $\begin{array}{l}11.5 \pm \\
0.002^{\mathrm{b}}\end{array}$ \\
\hline & $\mathrm{C}_{1} \mathrm{~A}_{3}$ & $3.59 \pm 0.19^{\mathrm{a}}$ & $2.82 \pm 0.17^{\mathrm{bc}}$ & $3.50 \pm 0.29^{\mathrm{b}}$ & $3.50 \pm 0.29^{\mathrm{a}}$ & $15.0 \pm 0.87^{\mathrm{b}}$ & $26.8 \pm 3.35^{\mathrm{ab}}$ & $45.0 \pm 1.22^{\mathrm{ab}}$ & $5.85 \pm 0.00^{c}$ \\
\hline & $\mathrm{C}_{1} \mathrm{~A}_{4}$ & $5.30 \pm 0.027^{\mathrm{d}}$ & $3.09 \pm 0.10^{\mathrm{cd}}$ & $2.25 \pm 0.25^{\mathrm{a}}$ & $3.00 \pm 0.41^{\mathrm{a}}$ & $11.5 \pm 0.50^{\mathrm{c}}$ & $26.8 \pm 2.28^{\mathrm{ab}}$ & $47.5 \pm 1.04^{\mathrm{ab}}$ & $4.75 \pm 0.00^{\mathrm{a}}$ \\
\hline & $\mathrm{C}_{2} \mathrm{~A}_{1}$ & $3.37 \pm 0.13^{\mathrm{a}}$ & $2.62 \pm 0.25^{\mathrm{bc}}$ & $2.25 \pm 0.25^{\mathrm{a}}$ & $3.00 \pm 0.41^{\mathrm{a}}$ & $24.0 \pm 0.71^{\mathrm{d}}$ & $27.8 \pm 0.85^{\mathrm{ab}}$ & $48.5 \pm 1.70^{\mathrm{b}}$ & $13.1 \pm 0.31^{\mathrm{d}}$ \\
\hline & $\mathrm{C}_{2} \mathrm{~A}_{2}$ & $4.44 \pm 0.17^{\mathrm{c}}$ & $3.68 \pm 0.14^{\mathrm{e}}$ & $4.50 \pm 0.29^{b}$ & $3.75 \pm 0.25^{\mathrm{a}}$ & $36.3 \pm 0.63^{\mathrm{e}}$ & $37.3 \pm 1.25^{\mathrm{c}}$ & $48.5 \pm 1.65^{\mathrm{b}}$ & $19.3 \pm 0.25^{\mathrm{e}}$ \\
\hline & $\mathrm{C}_{2} \mathrm{~A}_{3}$ & $5.79 \pm 0.13^{\mathrm{d}}$ & $3.38 \pm 0.18^{\mathrm{de}}$ & $3.75 \pm 0.25^{\mathrm{b}}$ & $4.00 \pm 0.41^{\mathrm{a}}$ & $33.5 \pm 1.70^{\mathrm{e}}$ & $37.5 \pm 1.19^{\mathrm{c}}$ & $65.3 \pm 1.88^{\mathrm{c}}$ & $16.3 \pm 0.02^{\mathrm{f}}$ \\
\hline & $\mathrm{C}_{2} \mathrm{~A}_{4}$ & $4.23 \pm 0.34^{\mathrm{bc}}$ & $3.58 \pm 0.15^{\mathrm{de}}$ & $2.00 \pm 0.41^{\mathrm{a}}$ & $3.75 \pm 0.63^{\mathrm{a}}$ & $11.5 \pm 0.96^{\mathrm{c}}$ & $31.3 \pm 1.37^{\mathrm{b}}$ & $39.5 \pm 0.50^{\mathrm{d}}$ & $3.93 \pm 0.28^{\mathrm{g}}$ \\
\hline
\end{tabular}

Note: Values in each rows with different letters are significantly different at $\mathrm{P}<0.05$. Values in rows with same letters are not significantly different. 
Table 3: Combined effects of different concentration of dill plant residues and cultivars on some chemical component of leaves, data represented as (mean \pm S.E.).

\begin{tabular}{|c|c|c|c|c|c|c|c|c|c|}
\hline & & $\begin{array}{c}\text { Total } \\
\text { chlorophyll } \\
\left(\mathrm{mg}^{-1}\right)^{-1}\end{array}$ & $\begin{array}{l}\text { Proline } \\
\text { (ppm) }\end{array}$ & $\begin{array}{c}\text { Total } \\
\text { nitrogen (\%) }\end{array}$ & Protein (\%) & $\begin{array}{c}\text { Total } \\
\text { phosphorus } \\
\left.\left(\mathrm{mg}^{-1}\right)^{-1}\right)\end{array}$ & $\mathrm{Fe}^{+3}(\mathrm{ppm})$ & $\mathrm{K}^{+}\left(\mathrm{mg} \cdot \mathrm{g}^{-1}\right)$ & $\mathrm{Na}^{+}\left(\mathrm{mg}^{-g^{-1}}\right)$ \\
\hline \multirow[t]{2}{*}{ Cultivars } & $\mathrm{C}_{1}$ & $0.637 \pm 0.017^{\mathrm{a}}$ & $56.87 \pm 1.17^{\mathrm{a}}$ & $7.26 \pm 0.03^{\mathrm{a}}$ & $18.45 \pm 0.08^{\mathrm{a}}$ & $49.45 \pm 0.46^{\mathrm{a}}$ & $8.54 \pm 0.214^{\mathrm{a}}$ & $29.18 \pm 0.31^{\mathrm{a}}$ & $0.996 \pm 0.01^{\mathrm{a}}$ \\
\hline & $\mathrm{C}_{2}$ & $0.696 \pm 0.017^{\mathrm{a}}$ & $97.12 \pm 1.17^{b}$ & $7.76 \pm 0.03^{b}$ & $19.80 \pm 0.08^{\mathrm{b}}$ & $42.97 \pm 0.46^{\mathrm{a}}$ & $8.10 \pm 0.214^{\mathrm{a}}$ & $22.51 \pm 0.31^{b}$ & $0.564 \pm 0.01^{b}$ \\
\hline \multirow{4}{*}{ 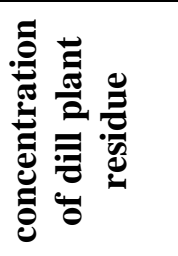 } & $A_{1}(0 \%)$ & $0.66 \pm 0.025^{\mathrm{a}}$ & $72.81 \pm 1.67^{\mathrm{ab}}$ & $7.03 \pm 0.04^{\mathrm{a}}$ & $17.78 \pm 0.11^{\mathrm{a}}$ & $49.32 \pm 0.65^{\mathrm{a}}$ & $9.43 \pm 0.30^{\mathrm{a}}$ & $23.93 \pm 0.44^{\mathrm{a}}$ & $1.100 \pm 0.014^{\mathrm{a}}$ \\
\hline & $A_{2}(2 \%)$ & $0.65 \pm 0.025^{\mathrm{a}}$ & $89.60 \pm 1.67^{\mathrm{c}}$ & $7.64 \pm 0.04^{b}$ & $19.61 \pm 0.11^{\mathrm{b}}$ & $47.37 \pm 0.65^{\mathrm{b}}$ & $9.87 \pm 0.30^{\mathrm{a}}$ & $23.22 \pm 0.44^{\mathrm{a}}$ & $0.395 \pm 0.014^{b}$ \\
\hline & $\mathrm{A}_{3}(4 \%)$ & $0.66 \pm 0.025^{\mathrm{a}}$ & $75.92 \pm 1.67^{b}$ & $6.82 \pm 0.04^{\mathrm{c}}$ & $19.84 \pm 0.11^{\mathrm{b}}$ & $18.04 \pm 0.65^{\mathrm{c}}$ & $6.70 \pm 0.30^{\mathrm{b}}$ & $29.04 \pm 0.44^{b}$ & $0.771 \pm 0.014^{c}$ \\
\hline & $\mathrm{A}_{4}(6 \%)$ & $0.70 \pm 0.025^{\mathrm{a}}$ & $69.66 \pm 1.67^{d}$ & $6.55 \pm 0.04^{b}$ & $17.28 \pm 0.11^{\mathrm{c}}$ & $70.13 \pm 0.65^{\mathrm{d}}$ & $7.28 \pm 0.30^{b}$ & $27.19 \pm 0.44^{\mathrm{c}}$ & $0.850 \pm 0.014^{\mathrm{d}}$ \\
\hline \multirow{8}{*}{ 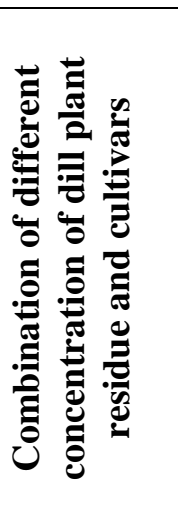 } & $\mathrm{C}_{1} \mathrm{~A}_{1}$ & $0.47 \pm 0.037^{\mathrm{a}}$ & $47.3 \pm 2.33^{\mathrm{a}}$ & $6.56 \pm 0.16^{\mathrm{a}}$ & $16.55 \pm 0.41^{\mathrm{a}}$ & $46.4 \pm 0.02^{\mathrm{a}}$ & $9.21 \pm 0.18^{\mathrm{ab}}$ & $20.7 \pm 0.65^{\mathrm{a}}$ & $0.97 \pm 0.005^{\mathrm{a}}$ \\
\hline & $\mathrm{C}_{1} \mathrm{~A}_{2}$ & $0.79 \pm 0.019^{\mathrm{bc}}$ & $60.9 \pm 2.01^{b}$ & $7.16 \pm 0.07^{b}$ & $18.34 \pm 0.16^{\mathrm{b}}$ & $32.7 \pm 0.24^{b}$ & $9.53 \pm 1.12^{\mathrm{ab}}$ & $29.7 \pm 0.95^{b}$ & $0.77 \pm 0.021^{\mathrm{c}}$ \\
\hline & $\mathrm{C}_{1} \mathrm{~A}_{3}$ & $0.75 \pm 0.029^{b}$ & $67.7 \pm 0.93^{b}$ & $7.60 \pm 0.00^{\mathrm{de}}$ & $19.28 \pm 0.16^{\mathrm{cd}}$ & $10.8 \pm 0.73^{\mathrm{c}}$ & $7.08 \pm 0.21^{\mathrm{cd}}$ & $31.8 \pm 0.42^{\mathrm{c}}$ & $1.01 \pm 0.019^{\mathrm{a}}$ \\
\hline & $\mathrm{C}_{1} \mathrm{~A}_{4}$ & $0.53 \pm 0.018^{\mathrm{a}}$ & $51.6 \pm 2.97^{\mathrm{a}}$ & $7.71 \pm 0.00^{\mathrm{e}}$ & $19.64 \pm 0.16^{\mathrm{d}}$ & $107.8 \pm 2.3^{\mathrm{d}}$ & $9.65 \pm 0.11^{\mathrm{ac}}$ & $34.6 \pm 0.24^{\mathrm{d}}$ & $1.24 \pm 0.018^{b}$ \\
\hline & $\mathrm{C}_{2} \mathrm{~A}_{1}$ & $0.84 \pm 0.013^{\mathrm{bc}}$ & $98.4 \pm 1.99^{\mathrm{d}}$ & $7.49 \pm 0.00^{\mathrm{cd}}$ & $19.00 \pm 0.16^{\mathrm{c}}$ & $52.2 \pm 0.39^{\mathrm{e}}$ & $10.2 \pm 0.27^{\mathrm{ab}}$ & $27.2 \pm 1.03^{\mathrm{e}}$ & $1.24 \pm 0.000^{b}$ \\
\hline & $\mathrm{C}_{2} \mathrm{~A}_{2}$ & $0.51 \pm 0.006^{\mathrm{a}}$ & $118.3 \pm 2.5^{\mathrm{e}}$ & $8.13 \pm 0.00^{\mathrm{g}}$ & $20.88 \pm 0.16^{\mathrm{e}}$ & $62.1 \pm 0.00^{f}$ & $6.32 \pm 0.03^{b}$ & $16.8 \pm 0.16^{\mathrm{f}}$ & $0.025 \pm 0.003^{\mathrm{d}}$ \\
\hline & $\mathrm{C}_{2} \mathrm{~A}_{3}$ & $0.56 \pm 0.040^{\mathrm{a}}$ & $84.1 \pm 3.86^{c}$ & $8.03 \pm 0.00^{\mathrm{g}}$ & $20.40 \pm 0.16^{\mathrm{f}}$ & $25.2 \pm 0.85^{\mathrm{g}}$ & $6.32 \pm 0.19^{d}$ & $26.3 \pm 0.31^{\mathrm{e}}$ & $0.53 \pm 0.044^{\mathrm{e}}$ \\
\hline & $\mathrm{C}_{2} \mathrm{~A}_{4}$ & $0.87 \pm 0.074^{\mathrm{c}}$ & $87.7 \pm 0.40^{\mathrm{c}}$ & $7.38 \pm 0.00^{c}$ & $18.91 \pm 0.16^{\mathrm{c}}$ & $32.4 \pm 0.00^{b}$ & $6.23 \pm 0.05^{\mathrm{d}}$ & $19.8 \pm 0.62^{\mathrm{a}}$ & $0.46 \pm 0.000^{\mathrm{f}}$ \\
\hline
\end{tabular}

Note: Nitrogen, protein and proline data that represented in percentage were converted to angular transformation. 


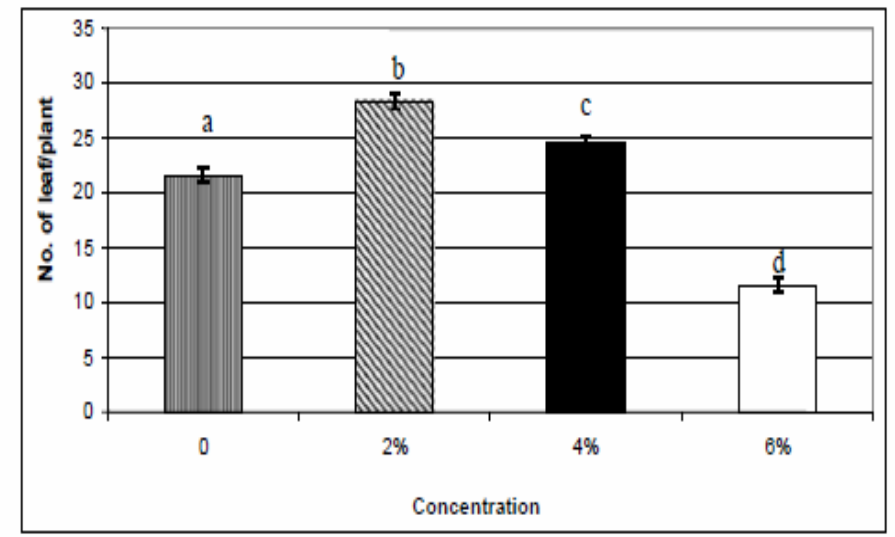

Figure (1): Effect of different concentration of dill plant residue on number of leaf per plant, data represented as (mean \pm S.E.).

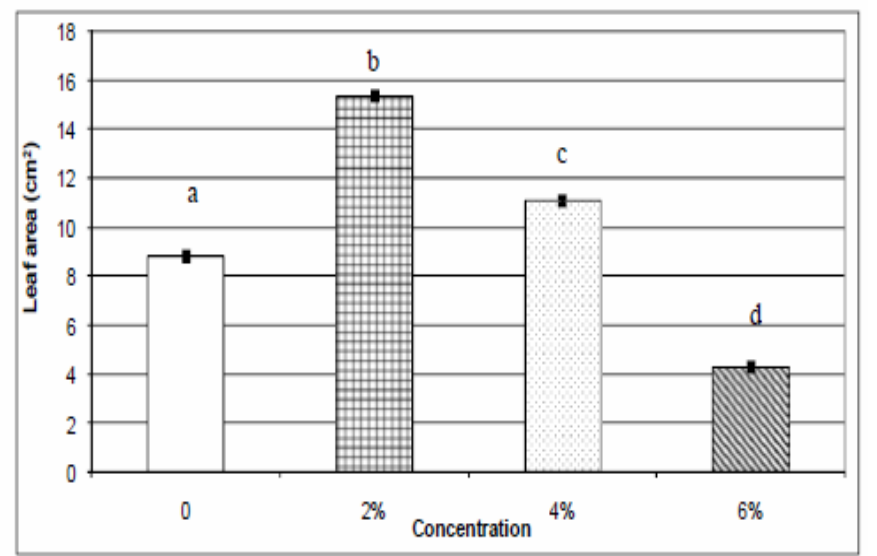

Figure (2): Effect of different concentration of dill plant residue on leaf area $\left(\mathrm{cm}^{2}\right)$, data represented as (mean \pm S.E.)

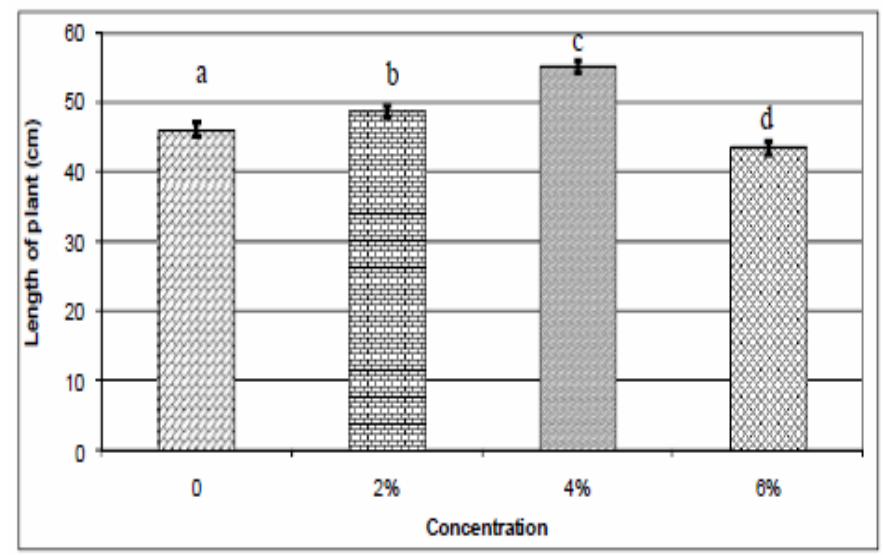

Figure (3): Effect of different concentration of dill plant residue on length of plant (cm), data represented as (mean \pm S.E.).

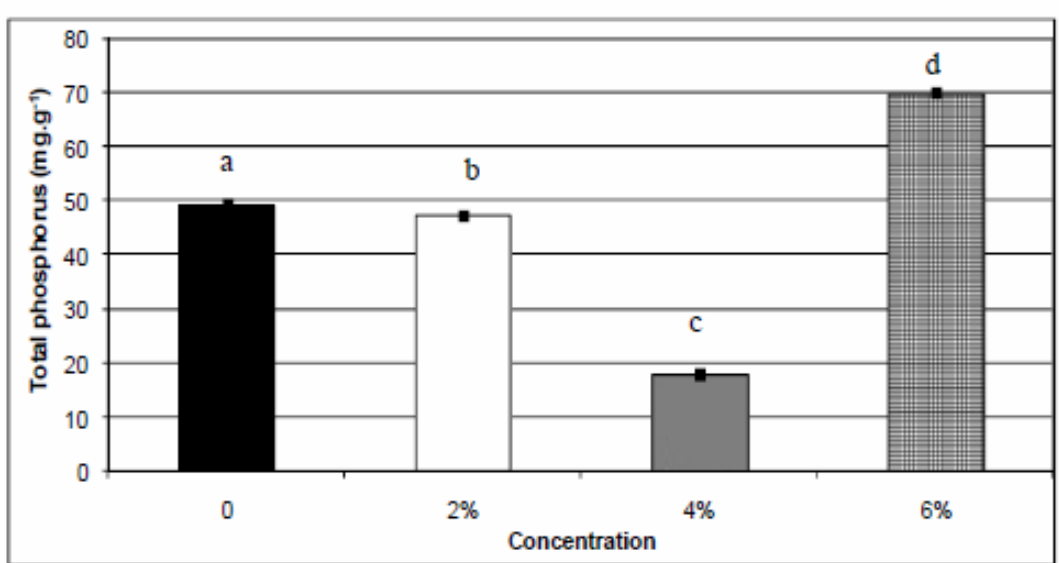

Figure (4): Effect of different concentration of dill plant residue on total phosphorus $\left(\mathrm{mg} \cdot \mathrm{g}^{-1}\right)$ of barley leaf, data represented as (mean \pm S.E.).

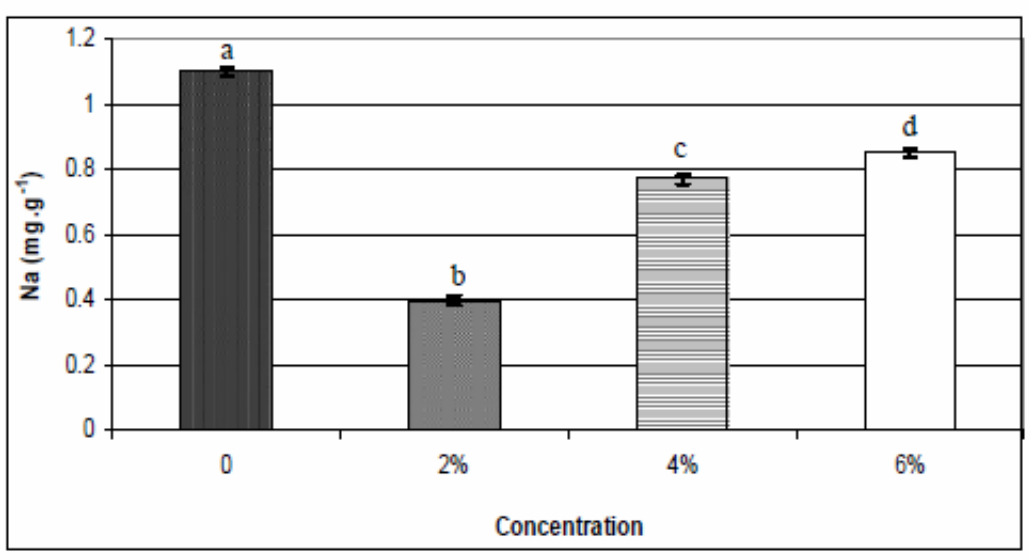

Figure (5): Effect of different concentration of dill plant residue on sodium content $\left(\mathrm{mg} \cdot \mathrm{g}^{-1}\right)$ of barley leaf, data represented as (mean \pm S.E.). 
Table 4: Combined effects of different concentration of dill plant residues and cultivars on some chemical component of seeds, data represented as (mean \pm S.E.).

\begin{tabular}{|c|c|c|c|c|c|c|c|}
\hline & & $\begin{array}{c}\text { Total nitrogen } \\
(\%)\end{array}$ & Protein (\%) & $\begin{array}{c}\text { Total phosphorus } \\
\left.\text { (mg. } \text { g }^{-1}\right)\end{array}$ & $\mathrm{Fe}^{+3}(\mathrm{ppm})$ & $\mathrm{K}^{+}\left(\mathrm{mg} \mathrm{g}^{-1}\right)$ & $\mathrm{Na}^{+}\left(\mathrm{mg} \mathrm{g}^{-1}\right)$ \\
\hline \multirow[t]{2}{*}{ Cultivars } & $\mathrm{C}_{1}$ & $6.60 \pm 0.078^{\mathrm{a}}$ & $16.96 \pm 0.19^{\mathrm{a}}$ & $10.64 \pm 0.014^{\mathrm{a}}$ & $2.80 \pm 0.053^{\mathrm{a}}$ & $27.03 \pm 0.18^{\mathrm{a}}$ & $1.00 \pm 0.01^{\mathrm{a}}$ \\
\hline & $\mathrm{C}_{2}$ & $7.16 \pm 0.078^{b}$ & $18.18 \pm 0.19^{b}$ & $43.46 \pm 0.014^{\mathrm{b}}$ & $3.26 \pm 0.053^{\mathrm{a}}$ & $22.16 \pm 0.18^{b}$ & $0.77 \pm 0.01^{\mathrm{a}}$ \\
\hline \multirow{4}{*}{ 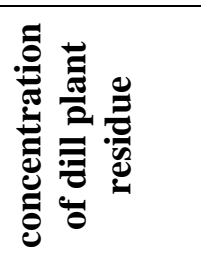 } & $\mathrm{A}_{1}(0 \%)$ & $6.59 \pm 0.11^{\mathrm{a}}$ & $17.08 \pm 0.26^{\mathrm{a}}$ & $11.70 \pm 0.019^{\mathrm{a}}$ & $3.66 \pm 0.074^{\mathrm{a}}$ & $22.27 \pm 0.25^{\mathrm{a}}$ & $0.72 \pm 0.015^{\mathrm{a}}$ \\
\hline & $\mathrm{A}_{2}(2 \%)$ & $7.29 \pm 0.11^{b}$ & $18.12 \pm 0.26^{\mathrm{b}}$ & $21.18 \pm 0.019^{b}$ & $2.53 \pm 0.074^{\mathrm{b}}$ & $20.85 \pm 0.25^{b}$ & $0.58 \pm 0.015^{\mathrm{b}}$ \\
\hline & $\mathrm{A}_{3}(4 \%)$ & $6.23 \pm 0.11^{\mathrm{c}}$ & $15.96 \pm 0.26^{\mathrm{c}}$ & $40.31 \pm 0.019^{c}$ & $2.49 \pm 0.074^{\mathrm{b}}$ & $23.40 \pm 0.25^{\mathrm{c}}$ & $0.86 \pm 0.015^{\mathrm{c}}$ \\
\hline & $A_{4}(6 \%)$ & $7.43 \pm 0.11^{\mathrm{b}}$ & $19.13 \pm 0.26^{\mathrm{d}}$ & $34.65 \pm 0.019^{\mathrm{d}}$ & $3.44 \pm 0.074^{\mathrm{c}}$ & $31.87 \pm 0.25^{\mathrm{d}}$ & $1.39 \pm 0.015^{\mathrm{d}}$ \\
\hline \multirow{8}{*}{ 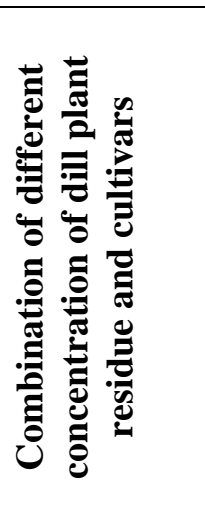 } & $\mathrm{C}_{1} \mathrm{~A}_{1}$ & $6.55 \pm 0.16^{\mathrm{ab}}$ & $16.74 \pm 0.37^{\mathrm{ab}}$ & $15.89 \pm 0.00^{\mathrm{a}}$ & $2.44 \pm 0.07^{\mathrm{ab}}$ & $21.38 \pm 0.51^{\mathrm{a}}$ & $0.66 \pm 0.030^{\mathrm{a}}$ \\
\hline & $\mathrm{C}_{1} \mathrm{~A}_{2}$ & $7.06 \pm 0.16^{\mathrm{d}}$ & $18.03 \pm 0.37^{\text {cd }}$ & $11.24 \pm 0.00^{\mathrm{b}}$ & $3.28 \pm 0.20^{\mathrm{d}}$ & $29.58 \pm 0.56^{\mathrm{b}}$ & $0.91 \pm 0.020^{\mathrm{b}}$ \\
\hline & $\mathrm{C}_{1} \mathrm{~A}_{3}$ & $6.37 \pm 0.16^{\mathrm{ab}}$ & $16.09 \pm 0.37^{\mathrm{a}}$ & $8.25 \pm 0.064^{\mathrm{c}}$ & $2.72 \pm 0.07^{\mathrm{bc}}$ & $28.26 \pm 0.00^{\mathrm{c}}$ & $1.39 \pm 0.016^{\mathrm{c}}$ \\
\hline & $\mathrm{C}_{1} \mathrm{~A}_{4}$ & $6.44 \pm 0.16^{\mathrm{ab}}$ & $17.00 \pm 0.37^{\mathrm{abc}}$ & $6.47 \pm 0.022^{\mathrm{d}}$ & $2.76 \pm 0.10^{c}$ & $28.90 \pm 0.45^{\mathrm{bc}}$ & $1.04 \pm 0.030^{\mathrm{d}}$ \\
\hline & $\mathrm{C}_{2} \mathrm{~A}_{1}$ & $6.63 \pm 0.16^{\text {bg }}$ & $17.43 \pm 0.37^{\text {bcd }}$ & $7.52 \pm 0.027^{\mathrm{e}}$ & $4.88 \pm 0.13^{\mathrm{e}}$ & $23.14 \pm 0.43^{d}$ & $0.78 \pm 0.020^{\mathrm{e}}$ \\
\hline & $\mathrm{C}_{2} \mathrm{~A}_{2}$ & $7.51 \pm 0.16^{\mathrm{eg}}$ & $18.01 \pm 0.37^{\mathrm{d}}$ & $31.1 \pm 0.025^{\mathrm{f}}$ & $1.78 \pm 0.04^{\mathrm{f}}$ & $12.12 \pm 0.06^{\mathrm{e}}$ & $0.25 \pm 0.002^{\mathrm{f}}$ \\
\hline & $\mathrm{C}_{2} \mathrm{~A}_{3}$ & $6.10 \pm 0.16^{\mathrm{c}}$ & $15.83 \pm 0.37^{\mathrm{e}}$ & $72.38 \pm 0.00^{\mathrm{g}}$ & $2.25 \pm 0.07^{\mathrm{a}}$ & $18.54 \pm 0.19^{\mathrm{f}}$ & $0.32 \pm 0.030^{\mathrm{g}}$ \\
\hline & $\mathrm{C}_{2} \mathrm{~A}_{4}$ & $8.42 \pm 0.16^{\mathrm{d}}$ & $21.25 \pm 0.37^{\mathrm{f}}$ & $62.83 \pm 0.00^{\mathrm{h}}$ & $4.12 \pm 0.06^{\mathrm{g}}$ & $34.83 \pm 0.01^{\mathrm{g}}$ & $1.73 \pm 0.006^{\mathrm{h}}$ \\
\hline
\end{tabular}

Note: Nitrogen, protein and proline data that represented in percentage were converted to angular transformation. 


\section{REFERENCES}

Ahmed, N.; Amanulla; Jamal, T.; Munir, I.; Ali, A. ; Khan, M. (2007). Residual effect of nitrogen applied to maize on yield of barlery. Sarhad J. Agriculture. 23(3), 549552.

Amin, S. A. (2010). Responses of four barley (Hordeum valgare L.) cultivars to water stress periods. Zanco. 22(4),93- 103.

Ashafi, Z.Y.; Sadeghi, S. ; Mashhadi, H.R. (2009). Inhibitive effects of barley (Horedeum vulgare) on germination and growth of seedling quack grass (Agropyrum repens). Iceland Agricultural Scie. 22, 37- 43.

Ashafi, Z.Y.; Sadeghi, S.; Mashhadi, H.R. ; Alizade, H.M. (2008). Study of allelopathical effects of barley on inhibition of germination and growth of seedling green foxtail. J. SAT Agricultural Research. 6, 1- 6.

Badar, N.; Arshad, M. ; Farooq, U. (2008). Characteristics of Anethum graveolens (Umbelliferae) seed oil: Extraction, composition and antimicrobial activity. International J. agriculture and Biol. 10(3), 329-332.

Bates, L.W.; Waldren, R.P. ; Teart, I.D. (1973). Rapid determination of proline for water stress studies. Plant and Soil. 39, 205- 207.

Callan, N.W.; Johnson, D.L.; Westcott, M.P. ; Welty, L.E. (2007). Herb and oil composition of dill (Anethum graveolens L.): Effects of crop maturity and plant density. Industrial Crops and products. 25(3), 282- 287.

Choe, J.H.; Jang, A.; Choi, J.H.; Choi, Y.S.; Han, D.J.; Kim, H.Y.; Lee, M.A.; Kim, H. W. ; Kim, C.J. (2010). Antioxidant activities of lotus leaves (Nelumbo nucifera) and barley leaves (Horedeum vulgare) extracts. Food Scie. Biotechnol. 19(3), 831- 836.

Chon, S.U. ; Kim, J.D. (2002). Biological activity and quantification of suspected allelochemicals from alfalfa plant parts. J. Agronomical Crop Scie. 188, 248- 253.

Dhima, K.V.; Vasilakoglou, I.B.; Gatsis, T.H.D.; Panou-Philotheou, E. ; Eleftherohorinos I.G. (2009). Effects of aromatic plants incorporated as green manure on weed and maize development. Field Crops Res. 110, 235-241.

Dhima, K.V.; Vasilakoglou, I.; Garane, V.; Ritzoulis, C.; Lianopoulou, V. ; PanouPhilotheou, E. (2010). Competitiveness and essential oil phytotoxicity of seven annual aromatic plants. Weed Scie . 58, 457- 465.

Economou, G.O.; Tzakou, A.; Gani, A.; Yannitsaro; Bilbas, D. (2002). Allelopathic effect of Conyza albida. Ecol. J. 17, 2021- 2034.

Edrisi, S. ; Farahbakhsh, A. (2011). Germination of barley as affected by the allelopathy of Sisymbrium irrio L. and Descurainia Sophia L. Schur. World Academy of Scie., Engineering and Technology. 74, 650- 652.

El- Rokiek, K. G.; El- Din, S.A.S. ; Sharara, F.A.A. (2010). Allelopathic behaviour of Cyperus rotundus L. on both Chochorus olitorius (Bread leaved weed) and Echinochloa crus- galli (grassy weed) associated with soybean. J. Plant Protection Research. 50(3), 274- 279.

Hellal, F.A.; Mahfouz, S.A. ; Hassan, F.A.S. (2011). Partial substitution of mineral nitrogen fertilizer by bio- fertilizer on (Anethum graveolens L.) plant. Agriculture and Biol. J. North America. 2(4), 652- 660. 
Kivi, M.P. ; Toheh, A. (2010). Inhibitory impact of some crop plants extracts on germination and growth of wheat. American- Eurasian J. Agriculture and Environmental Scie. 9(1), 47- 51.

Knudsen, L.L.; Tibbitts, T.W. ; Edwards, G.E. (1997). Measurement of ozone injury by etermination of chlorophyll concentration. Plant Physio. 60, 606- 608.

Kremer, R.J. ; Ben- Hammouda, M. (2009). Allelopathic plants. 19. Barley (Horedeum vulgare L.). Allelopathy J., 24(2), 225- 242.

Mutlu, S. ; Atiei, O. (2009). Allelopathic effect of Nepeta meyeri Benth. Extracts on seed germination and seedling growth of some crop plants. Acta physiology Plant. 31, 89- 93.

Ninkovic, V. (2003). Volatile communication between barley plants affects biomass allocation. J. Experimental Botany. 54(389), 1931- 1939.

Queslati, O.; Ben- Hammouda, M.; Ghorbal, M.H.; Guezzah, M. ; Kremer, R.J. (2005). Barley autotoxicity as influenced by vertical and seasonal variation. J. Agronomy and Crop Scie. 191, 249- 254.

Radulescu, V.; Popescu, M.L. ; Ilies, D.C. (2010). Chemical composition of the volatile oil from different plant parts of Anethum graveolens L. (Umbelliferae) cultivated in Romania. Farmacia. 58(5), 594- 600.

Ryan, J.; Estefon, G. ; Rashid, A. (2001). Soil and plant analysis laboratory manual. 2nd edn. National Agriculture Research Center (NARC). Islamabad, Pakistan.

Schuffelen, A.; Miller, A. ; Vanscnouwenbuing, J.G.H. (1960). Quick tests for soil and plant analysis used by small laboratories. Netherland J. Agricul. Scie. 9, 2 -16.

Vogel, I. (1961). "A Text Book of Quantitative in Organic Analysis". Longman. London.

Xing, S. (2009). The impact of dill weed, spearmint and clove essential oils on sprout suppression in potato tubers. M.Sc. Thesis. Saskatchewan University.

Zuo, S.; Ma, Y. ; Shinobu, I. (2008). Ecological adaptation of weed biodiversity to the allelopathic rank of the stubble of different wheat genotypes in a maize field. Weed Biol. and Management. 8, 161- 171. 